\title{
Evaluation of Organic Carbon from Anaerobic Sequencing Batch Reactor Effluent as a Carbon Source for Denitrification
}

\author{
David $\mathrm{NM}^{1 *}$, Eliud Nyaga MN ${ }^{1}$, George $\mathrm{O}^{1}$, Frank $\mathrm{K}^{2}$, John $\mathrm{O}^{3}$ and Joseph $\mathrm{K}^{3}$ \\ ${ }^{1}$ Department of Biochemistry and Biotechnology, School of Pure and Applied Science, Kenyatta University, Nairobi, Kenya \\ ${ }^{2}$ Institute of Environment and Natural Resources, Makerere University, Kampala, Uganda \\ ${ }^{3}$ Department of Biochemistry, School of Biological Sciences, Makerere University, Kampala, Uganda
}

"Corresponding author: David NM, Department of Biochemistry and Biotechnology, School of Pure and Applied Sciences, Kenyatta University, PO Box 43844-00100, Nairobi, Kenya, Tel: +254720261585; E-mail: mutua.david@ku.ac.ke

Received date: December 09, 2016 Accepted date: January 12, 2017; Published date: January 20, 2017

Copyright: ( 2017 David NM, et al. This is an open-access article distributed under the terms of the Creative Commons Attribution License, which permits unrestricted use, distribution, and reproduction in any medium, provided the original author and source are credited.

\begin{abstract}
The discharge of nitrate-rich effluent has adverse effect on the receiving environment and the public health of the polluted water users. The nitrates are eliminated in a denitrification step that requires reducing power in form of organic carbon. The objective of this study was to evaluate the potential of utilizing organic carbon in effluent from the anaerobic SBR as a carbon source for denitrification. Reactors were operated for one year using meat processing wastewater. Anaerobically treated abattoir wastewater equivalent to 5,10 and $15 \%$ of aerobic SBR hydraulic volume were added to three separate reactors. A $12 \mathrm{~h}$ operating cycle consisted of the following periods: (a) filling, $0.30 \mathrm{~h}$; (b) settling, $11 \mathrm{~h}$ and (d) decanting, $0.30 \mathrm{~h}$ for the anoxic reactor. A comparison between different carbon loads was performed based on biological carbon, nitrogen and phosphorus removal. Sufficient denitrification was achieved with $10 \%$ (aerobic SBR hydraulic volume) of anaerobically-treated abattoir wastewater. TCOD, BOD , $\mathrm{TKN}, \mathrm{NO}_{2}{ }^{-} \mathrm{N}, \mathrm{NO}_{3}{ }^{-} \mathrm{N}, \mathrm{PO}_{4}{ }^{3-}, \mathrm{TS}, \mathrm{EC}$ and temperature and turbidity were reduced by $78,70,91,100,98,62,39,65$, 71,5 and $39 \%$ respectively, with effluent mean concentrations of $80 \pm 5 \mathrm{mg} / \mathrm{L}, 54 \pm 12 \mathrm{mg} / \mathrm{L}, 35 \pm 4,00 \pm 0,2 \pm 1,18$ $\pm 1,254 \pm 12,1.64 \pm 0.01,22.04 \pm 0.02$ and $738 \pm 9$ FAU. Organic carbon in effluent from the anaerobic SBR can be used as a carbon source for anoxic denitrification. However, the denitrification rate is affected by the organic carbon load used. Except TKN and o-PO43- mg/L, all other parameters in the denitrified effluent met discharge standards.
\end{abstract}

Keywords: Biological treatment; Denitrification; Nitrate; Organic carbon; Sequencing batch reactors (SBR); Wastewater

\section{Introduction}

The discharge of nitrate-rich effluent has adverse effect on the receiving environment and the public health of the polluted water users [1,2]. Such effects manifest as toxicity to aquatic biota, eutrophication $[3,4]$ and public health complications such as thyroid hypertrophy, methemoglobinemia, hypertension and cancer [5]. The World Health Organization has set a limit of 10 and $100 \mathrm{mg} / \mathrm{L} \mathrm{NO}_{3}{ }^{-}$for human and animal consumption, respectively. Wastewater above these limits requires treatment [6-8].

Nitrates are biologically removed via denitrification, anoxic reduction of $\mathrm{NO}_{3}^{-} \rightarrow \mathrm{NO}_{2}^{-} \rightarrow \mathrm{NO} \rightarrow \mathrm{N}_{2} \mathrm{O} \rightarrow \mathrm{N}_{2}$ by heterotrophic bacteria such as Pseudonomas stutzeri, Alcaligenes faecalis and Ochrobactrum anthropi $[9,10]$. Activated sludge based sequencing batch reactor (SBR) allows the removal of carbon, nitrogen and phosphorus using a single reactor [11-13]. The key to efficient biological pollutant removal is transitioning between anaerobic, aerobic, and anoxic phases. Doing so promotes transformation of the carbon, nitrogen and phosphorus by triggering utilization of different electron acceptors and donors [14].

However, simultaneous phosphorus and nitrogen removal is not always successful $[13,15]$. Polyphosphate-accumulating organisms (PAO) and denitrifying bacteria are both heterotrophic $[9,10]$, and thus able to take up organic carbon under anaerobic conditions and store it for growth once a suitable electron acceptor is available
[14,16-18]. In combined denitrification and EBPR systems, organic carbon availability is usually the limiting parameter [19,20], denitrifers and PAOs directly compete for the available organic carbon $[11,21]$. Both processes are inhibited by this competition [13,22].

Insufficient denitrification is improved by addition of an external organic carbon such as such as glucose, ethanol, acetate, methanol, aspartate, formic acid $[18,23]$, molasses, sulfite waste liquor, whey and distillery stillage [24]. However, these solutions are costly, require an adaptation period, lead to excessive sludge production and are not always efficient [13]. Hence efficient and cost-effective solutions are needed.

The use of wastewater as an internal carbon source is a promising alternative [10]. However, denitrification is affected by the type and dose of the organic carbon source used, duration of each phase and time cycle. The choice of hydraulic retention times and sludge retention time is dependent on this optimization $[25,26]$. The objective of this study was to evaluate the potential of utilizing anaerobically treated meat processing wastewater as a carbon source for denitrification. A comparison between different carbon loads was performed based on biological carbon, nitrogen and phosphorus removal. 
Citation: David NM, Eliud Nyaga MN, George O, Frank K, John O, et al. (2017) Evaluation of Organic Carbon from Anaerobic Sequencing Batch Reactor Effluent as a Carbon Source for Denitrification. J Bioengineer \& Biomedical Sci 7: 214. doi:10.4172/2155-9538.1000214

Page 2 of 6

\section{Materials and Methods}

\section{Model reactors}

Three glass reactors (Figure 1), each with a total volume of $25 \mathrm{~L}$ and a working liquid volume of $20 \mathrm{~L}$ were set up at Makerere University Biochemistry Research Lab. These reactors were fed with nitrified effluent. To prepare the nitrified liquor, meat processing wastewater from City Abattoir, Kampala-Uganda was treated sequentially in anaerobic and aerobic SBR using a standard procedure as described by Mutua et al. [19].

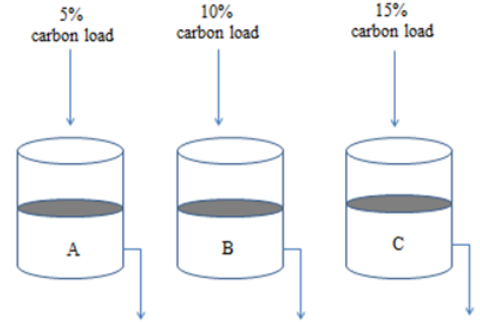

Figure 1: Schematic anoxic sequencing batch reactors.

Then, anaerobically treated abattoir wastewater equivalent to 5,10 and $15 \%$ of aerobic SBR hydraulic volume were added to three separate reactors (the properties of the anaerobically treated wastewater are shown in Table 1.

\begin{tabular}{|c|c|}
\hline Parameter & Outflow conc. \\
\hline TCOD & $3554 \pm 58$ \\
\hline SCOD & $762 \pm 3$ \\
\hline $\mathrm{BOD}_{5}$ & $1869 \pm 27$ \\
\hline TKN & $400 \pm 30$ \\
\hline $\mathrm{NH}_{4}-\mathrm{N}$ & $288 \pm 7$ \\
\hline $\mathrm{NO}_{2}-\mathrm{N}$ & NIL \\
\hline $\mathrm{NO}_{3}-\mathrm{N}$ & NIL \\
\hline TP & $129 \pm 1$ \\
\hline o- $\mathrm{PO}_{4}{ }^{3}-\mathrm{P}$ & $82 \pm 1$ \\
\hline Turbidity & $2800 \pm 9$ \\
\hline TS & $2307 \pm 21$ \\
\hline $\mathrm{pH}$ & $6.56 \pm 0.03$ \\
\hline EC & $3.02 \pm 0.01$ \\
\hline Temperature & $25.7 \pm 0.2$ \\
\hline
\end{tabular}

Table 1: Mean \pm standard error values of the physiochemical parameters determined for the anaerobic SBR effluent, $(n=6)$.

Concentrations of TCOD, SCOD, $\mathrm{BOD}_{5}, \mathrm{TKN}, \mathrm{NO}_{2}{ }^{-} \mathrm{N} \mathrm{NO}_{3}{ }^{-} \mathrm{N}$, TP, $\mathrm{o}-\mathrm{PO}_{4}{ }^{3-}$, Turbidity and TS are expressed in $\mathrm{mg} / \mathrm{L}$; Turbidity, EC, and temperature are expressed in $(\mathrm{FAU}),(\mathrm{ms} / \mathrm{cm})$ and $\left({ }^{\circ} \mathrm{C}\right)$, respectively.
An 12 hour operating cycle consisted of the following periods: (a) filling, $0.30 \mathrm{~h}$; (b) settling, $11 \mathrm{~h}$ and (d) decanting, $0.30 \mathrm{~h}$ for the anoxic reactors. At the end of each cycle, 10 litres of the supernatant was decanted, followed by feeding of an equal amount of wastewater. The system operated at a nominal Sludge Retention Time (SRT) of 5 days. The organic loading was $12.8 \mathrm{~kg} \mathrm{COD} / \mathrm{m}_{3} /$ day, during the study period. Steady-state conditions were obtained after 3 months.

\section{Analytical procedure}

Physical water quality variables (temperature, $\mathrm{pH}$ and electrical conductivity) were measured in situ per hour using portable WTW (Wissenchaftlich Technishe Werkstatten) microprocessor probes and meters. Chemical parameters such as total chemical oxygen demand (TCOD), biochemical oxygen demand $\left(\mathrm{BOD}_{5}\right)$, soluble chemical oxygen demand (SCOD), ammonia $\left(\mathrm{NH}_{3}\right)$, total kjeldahl nitrogen (TKN), nitrite $\left(\mathrm{NO}_{2}{ }^{-}\right)$, nitrate-nitrogen $\left(\mathrm{NO}_{3}{ }^{-}\right)$, total phosphorus (TP), ortho-phosphate $\left(\mathrm{o}-\mathrm{PO}_{4}{ }^{3-}\right.$ ), solids content (TSS) and turbidity were analyzed according to standard method.

\section{Statistical analysis}

One-way analysis of variance (ANOVA) was used to compare treatment means. The results were expressed as mean \pm SEM. The differences were considered significant, when $\mathrm{P}<0.05$.

\section{Results}

Figures 2 to 7 and Table 2 show the denitrification efficiencies obtained when 5,10 and $15 \%$ organic carbon load were used.

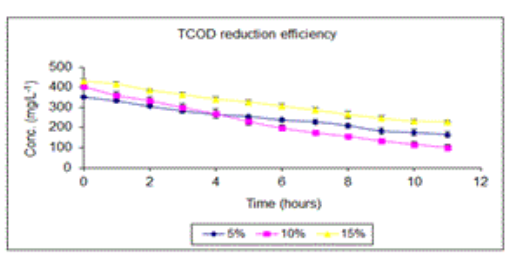

Figure 2: Comparison of TCOD removal efficiency in a denitrification step using 5,10 and $15 \%$ organic carbon load in a lab-scale SBR treating abattoir wastewater $(n=6)$.

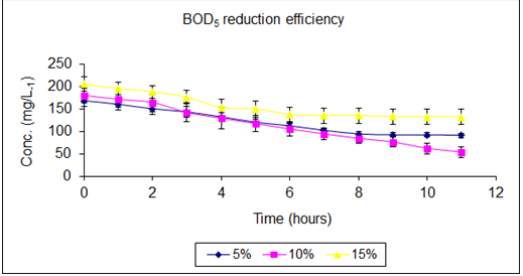

Figure 3: Comparison of $\mathrm{BOD}_{5}$ removal efficiency in a denitrification step using 5,10 and $15 \%$ organic carbon load in a lab-scale SBR treating abattoir wastewater $(n=6)$.

The TCOD removal efficiency significantly differed between $5 \%$ and each of $10 \%(\mathrm{p}=0.000)$ and $15 \%(\mathrm{p}=0.000)$ carbon load and the TCOD 
Citation: David NM, Eliud Nyaga MN, George O, Frank K, John O, et al. (2017) Evaluation of Organic Carbon from Anaerobic Sequencing Batch

Page 3 of 6

removal efficiency significantly differed between $10 \%$ and $15 \%$ carbon load $(\mathrm{p}=0.000)$ (Figure 2, Table 2).

The BOD removal efficiency did not significantly differ between $5 \%$ and each of $10 \%$ and $15 \%$ carbon load. However, there was significant difference in BOD removal efficiency between 10 and $15 \%$ carbon load $(\mathrm{p}=0.007)$ (Figure 3, Table 2).
The TKN removal efficiency significantly differed between $5 \%$ and each of $10 \%(\mathrm{p}=0.000)$ and $15 \%(\mathrm{p}=0.000)$ organic carbon load and the TKN removal efficiency significantly differed between $10 \%$ and $15 \%$ organic carbon load $(\mathrm{p}=0.000)$ (Table 2$)$.

\begin{tabular}{|c|c|c|c|c|c|}
\hline Parameter & Aerobic SBR effluent & Carbon load (\%) & Inflow conc. & Outflow Conc. & $\%$ Change \\
\hline \multirow[t]{3}{*}{ TCOD } & \multirow[t]{3}{*}{$332 \pm 16$} & 5 & $351 \pm 8$ & $165 \pm 12^{a}$ & -53 \\
\hline & & 10 & $359 \pm 9$ & $80 \pm 5$ & -78 \\
\hline & & 15 & $430 \pm 12$ & $229 \pm 7^{\mathrm{bc}}$ & -47 \\
\hline \multirow[t]{3}{*}{ BOD5 } & \multirow[t]{3}{*}{$164 \pm 20$} & 5 & $168 \pm 13$ & $91 \pm 5$ & -46 \\
\hline & & 10 & $180 \pm 16$ & $54 \pm 12$ & -70 \\
\hline & & 15 & $205 \pm 16$ & $132 \pm 17^{a}$ & -36 \\
\hline \multirow[t]{3}{*}{ TKN } & \multirow[t]{3}{*}{$186 \pm 12$} & 5 & $209 \pm 14$ & $165 \pm 18^{a}$ & -21 \\
\hline & & 10 & $225 \pm 2$ & $35 \pm 4$ & -91 \\
\hline & & 15 & $269 \pm 11$ & $229 \pm 10 b^{c}$ & -15 \\
\hline \multirow[t]{3}{*}{$\mathrm{NO}_{2}-\mathrm{N}$} & \multirow[t]{3}{*}{$115 \pm 9$} & 5 & $105 \pm 4$ & $43 \pm 6^{a}$ & -59 \\
\hline & & 10 & $93 \pm 17$ & $.00 \pm 0$ & -100 \\
\hline & & 15 & $82 \pm 9$ & $29 \pm 7^{a}$ & -65 \\
\hline \multirow[t]{3}{*}{$\mathrm{NO}_{3-} \mathrm{N}$} & \multirow[t]{3}{*}{$184 \pm 15$} & 5 & $172 \pm 13$ & $124 \pm 15^{\mathrm{a}}$ & -28 \\
\hline & & 10 & $122 \pm 1$ & $2 \pm 1$ & -98 \\
\hline & & 15 & $146 \pm 9$ & $115 \pm 7^{a}$ & -7 \\
\hline \multirow[t]{3}{*}{ TP } & \multirow[t]{3}{*}{$22 \pm 1$} & 5 & $26 \pm 4$ & $27 \pm 3$ & +4 \\
\hline & & 10 & $34 \pm 1$ & $18 \pm 1$ & -47 \\
\hline & & 15 & $48 \pm 9$ & $32 \pm 9$ & -33 \\
\hline \multirow[t]{3}{*}{$\mathrm{PO}_{4}^{3-}$} & \multirow[t]{3}{*}{$18 \pm 1$} & 5 & $16 \pm 1$ & $14 \pm 1$ & -1 \\
\hline & & 10 & $21 \pm 1$ & $8 \pm 1$ & -62 \\
\hline & & 15 & $33 \pm 6$ & $21 \pm 7$ & -36 \\
\hline \multirow[t]{3}{*}{ Turbidity } & \multirow[t]{3}{*}{$1015 \pm 6$} & 5 & $1156 \pm 28$ & $683 \pm 34$ & -41 \\
\hline & & 10 & $1210 \pm 16$ & $738 \pm 9$ & -39 \\
\hline & & 15 & $1325 \pm 54$ & $912 \pm 29^{a}$ & -31 \\
\hline \multirow[t]{3}{*}{ TS } & \multirow[t]{3}{*}{$655 \pm 12$} & 5 & $678 \pm 13$ & $217 \pm 10$ & -68 \\
\hline & & 10 & $729 \pm 7$ & $254 \pm 12$ & -65 \\
\hline & & 15 & $798 \pm 15$ & $365 \pm 19^{a}$ & -54 \\
\hline \multirow[t]{3}{*}{$\mathrm{pH}$} & \multirow[t]{3}{*}{$7.05 \pm 0.05$} & 5 & $6.93 \pm 0.03$ & $6.96 \pm 0.13^{a}$ & 0 \\
\hline & & 10 & $6.81 \pm 0.04$ & $7.00 \pm 0.0$ & -27 \\
\hline & & 15 & $6.45 \pm 0.13$ & $6.75 \pm 0.07^{\mathrm{a}}$ & -4 \\
\hline EC & $4.18 \pm 0.02$ & 5 & $5.27 \pm 0.02$ & $3.34 \pm 0.1^{a}$ & -37 \\
\hline
\end{tabular}


Citation: David NM, Eliud Nyaga MN, George O, Frank K, John O, et al. (2017) Evaluation of Organic Carbon from Anaerobic Sequencing Batch Reactor Effluent as a Carbon Source for Denitrification. J Bioengineer \& Biomedical Sci 7: 214. doi:10.4172/2155-9538.1000214

Page 4 of 6

\begin{tabular}{|l|l|l|l|l|l|}
\hline & & 10 & $5.69 \pm 0.1$ & $1.64 \pm 0.01$ & -71 \\
\cline { 3 - 6 } & & 15 & $5.86 \pm 0.14$ & $3.64 \pm 0.09^{\mathrm{a}}$ & -38 \\
\hline \multirow{2}{*}{ Temperature } & $22.06 \pm 0.1$ & 5 & $23.02 \pm 0.1$ & $22.72 \pm 0.02$ & -1 \\
\cline { 3 - 6 } & & 10 & $23.23 \pm 0.8$ & $22.04 \pm 0.02^{\mathrm{a}}$ & -5 \\
\cline { 3 - 6 } & & 15 & $23.49 \pm 0.11$ & $22.09 \pm 0.02^{\mathrm{a}}$ & -6 \\
\hline
\end{tabular}

Table 2: Mean \pm standard error values of physiochemical parameter determined in anoxic denitrification using 5, 10 and $15 \%$ (of the aerobic SBR hydraulic volume) carbon load from anaerobic SBR $(n=6)$.

Concentrations of TCOD, $\mathrm{BOD}_{5}, \mathrm{TKN}, \mathrm{NO}_{2}{ }^{-} \mathrm{N}, \mathrm{NO}_{3}{ }^{-} \mathrm{N}, \mathrm{TP}, \mathrm{PO}_{4}{ }^{3-}$, and TS are expressed in $\mathrm{mg} / \mathrm{L}$; Turbidity, EC, and temperature are expressed in (FAU), $\left(\mathrm{ms} / \mathrm{cm}^{3}\right)$ and $\left({ }^{\circ} \mathrm{C}\right)$, respectively. - signifies reduction, + signifies increment.

The NH4-H removal efficiency did not significantly differ between $5 \%$ and each of $10 \%$. However, there was significant difference in $\mathrm{NH}^{-}$ $\mathrm{H}$ removal efficiency between $15 \%$ each of 5 and $10 \%$ carbon load $(\mathrm{p}=0.007)$ (Table 2).

The $\mathrm{NO}_{2}{ }^{-} \mathrm{N}$ removal efficiency significantly differed between $10 \%$ and each of $5 \%(p=0.004)$ and $15 \%(p=0.004)$ carbon load. However, there was no significant difference in $\mathrm{NO}_{2}{ }^{-} \mathrm{N}$ removal efficiency between $5 \%$ and $15 \%$ carbon load $(\mathrm{p}>0.05$ ) (Figure 4 , Table 2 ).

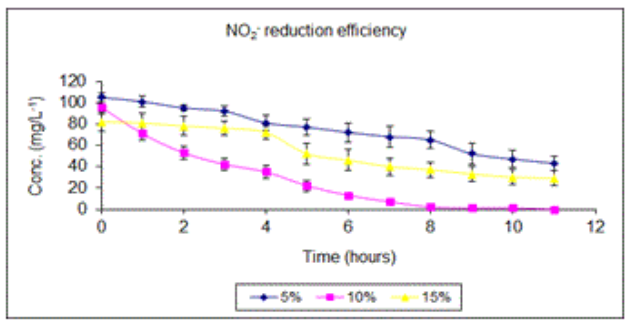

Figure 4: Comparison of $\mathrm{NO}_{2}{ }^{-} \mathrm{N}$ removal efficiency in a denitrification step using 5, 10 and $15 \%$ organic carbon load in a lab-scale SBR treating abattoir wastewater $(n=6)$.

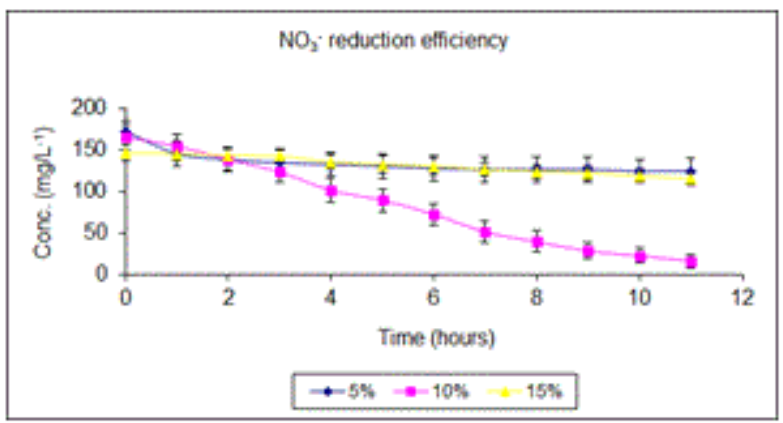

Figure 5: Comparison of $\mathrm{NO}_{3}{ }^{-} \mathrm{N}$ removal efficiency in a denitrification step using 5,10 and $15 \%$ organic carbon load in a lab-scale SBR treating abattoir wastewater $(n=6)$.
The $\mathrm{NO}_{3}{ }^{-} \mathrm{N}$ removal efficiency significantly differed between $10 \%$ and each of $5 \%(p=0.000)$ and $15 \%(p=0.000)$ carbon load. However, there was no significant difference in $\mathrm{NO}_{3}{ }^{-} \mathrm{N}$ removal efficiency between $5 \%$ and $15 \%$ carbon load ( $>0.05$ ) (Figure 5, Table 2). The TP and $\mathrm{PO}_{4}{ }^{3}$ - removal efficiency did not significantly differ between and among 5\%,10\% and 15\% organic carbon load used (Figures 6 and 7, Table 2).

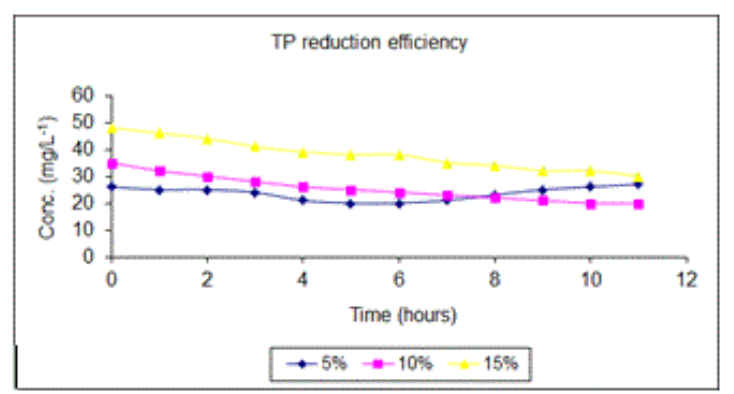

Figure 6: Comparison of TP removal efficiency in a denitrification step using 5, 10 and $15 \%$ organic carbon load in a lab-scale SBR treating abattoir wastewater, $(\mathrm{n}=6)$.

The turbidity removal efficiency did not significantly differ between $5 \%$ and $10 \%(\mathrm{p}>0.05)$ carbon load. However, there was significant difference in turbidity removal efficiency between $15 \%$ and each of $5 \%$ and $10 \%$ organic carbon load $(\mathrm{p}<0.05)$ (Table 2$)$.

The TS removal efficiency did not significantly differ between $5 \%$ and $10 \% \quad(p>0.05)$ carbon load. However, there was significant difference in TS removal efficiency between $15 \%$ and each of $5 \%$ and $10 \%$ organic carbon load $(\mathrm{p}<0.05)$ (Table 2). The $\mathrm{pH}$ did not significantly differ between $5 \%$ and $15 \%(\mathrm{p}>0.05)$ organic carbon load. However, there was significant difference in $\mathrm{pH}$ between $10 \%$ and each of $5 \%$ and $15 \%$ organic carbon load $(\mathrm{p}<0.05)$ (Table 2$)$.

The EC did not significantly differ between $5 \%$ and $15 \%(\mathrm{p}>0.05)$ organic carbon load. However, there was significant difference in EC between $10 \%$ and each of $5 \%$ and $15 \%$ organic carbon load $(\mathrm{p}<0.05)$ (Table 2). Temperature did not significantly differ between $10 \%$ and $15 \%(p>0.05)$ organic carbon load. However, there was significant difference in temperature between $5 \%$ and each of $10 \%$ and $15 \%$ organic carbon load $(\mathrm{p}<0.05)$ (Table 2$)$. 


\section{Discussion}

The National Environmental Management Authority (NEMA) has set wastewater discharge standards of: $\mathrm{COD}, 100 \mathrm{mg} / \mathrm{L} ; \mathrm{NH}_{4}{ }^{-} \mathrm{N}, 10$ $\mathrm{mg} / \mathrm{L}$, TKN, $10 \mathrm{mg} / \mathrm{L}$; TSS, $100 \mathrm{mg} / \mathrm{L}$; ortho-P, $5 \mathrm{mg} / \mathrm{L}$ and total-P, 10 $\mathrm{mg} / \mathrm{L}$; and Turbidity, 300 NTU/FAU; [19]. Effluent above these limits needs further processing to reduce pollutant concentrations.

Denitrification is anoxic reduction of the $\mathrm{NO}_{3}{ }^{-} \rightarrow \mathrm{NO}_{2}{ }^{-} \rightarrow \mathrm{NO} \rightarrow$ $\mathrm{N}_{2} \mathrm{O} \rightarrow \mathrm{N}_{2}$ by heterotrophic bacteria such as Pseudonomas stutzeri, Alcaligenes faecalis and Ochrobactrum anthropi [9,10]. Most denitrifiers are facultative heterotrophic bacteria that use organic carbon as energy source and nitrite-nitrates as electron acceptors [15]. While most waters contain a reducing power in the form of organic substrate, it is difficult to preserve the reducing power required for denitrification, due to the necessary preceding aerobic oxidation step $[24,26]$. Consequently, sufficient organic carbon source must be provided for proper denitrification [18].

Limited carbon is known to cause repression of denitrifying enzymes [11] as shown when $5 \%$ organic carbon (C:N ratio 1.68 ) is added (Figures 2 and 3). The current interpretation of this phenomenon is that nitrate entering the anoxic phase is used as an electron acceptor in the growth of non-poly heterotrophs [14]. This reduces the amount of the substrate available for sequestration by the poly organisms and hence reduces the amount of phosphorous removal that can be achieved [15]. Moreover, phosphate removal efficiency is affected by competition for the organic substrate between denitrifiers and PAOs $[13,19]$ leading to high phosphorus concentration in the effluent (Figure 7, Table 2).

$10 \%$ organic carbon load had a C:N ratio of $1.89 \mathrm{mg}$ COD.L $\mathrm{L}^{-1} \mathrm{~N}-$ TKN which achieved complete nitrite removal (Figure 4). Negligible amounts of nitrates $(2 \pm 1 \mathrm{mg} / \mathrm{L})$ remained within the system (Figure 5, Table 2). This is consistent with research findings by Obaja et al. [25] and Rahman et al. [24] that complete denitrification is obtained when the $\mathrm{C} / \mathrm{N}$ ratio is $\geq 1.7$. According to Fabregas [27], the high DO concentration $\left(14.40 \mathrm{mg} / \mathrm{L}^{-1}\right)$ at the beginning of anoxic period could have lowered the level of biodegradability of the wastewater and hence complete nitrate removal was not achieved. Carbon decrease observed was as a result of both assimilative and dissimilative carbon utilization by denitrifying and other bacteria [20,24]. The COD concentration measured at the end of the cycle was from the fraction of slowly biodegradable substrate contained in the abattoir wastewater [15]. Denitrification resulted in a rise in alkalinity of the system $[13,28,29]$, with corresponding increase in $\mathrm{pH}$ (Table 2).

The rate of phosphate removal increases (Figures 6 and 7) after most of the denitrification had taken place because denitrifers have high affinity for organic carbon than PAOs [11]. The phosphorus uptake under anoxic conditions is attributable to the activity of denitrifying phosphorus accumulating organisms (DNPAO), capable of accumulating high amounts of polyphosphates [20]. Towards the end of anoxic phase, orthophosphorus had a slight increase with no corresponding total phosphorus increase. This observation can be attributed to anoxic orthophosphorus release by PAOs and total phosphorus absorption by sediments [22].

The use of $15 \%$ organic carbon load decreases C:N ratio (1.59). This system overload inhibits both denitrifiers and PAOs activity [13,15], decreasing nitrates and ortho-phosphorus removal efficiencies. The initial high $\mathrm{NO}_{2}$ and $\mathrm{NO}_{3}$ - removal efficiencies were likely due to dilution factor.

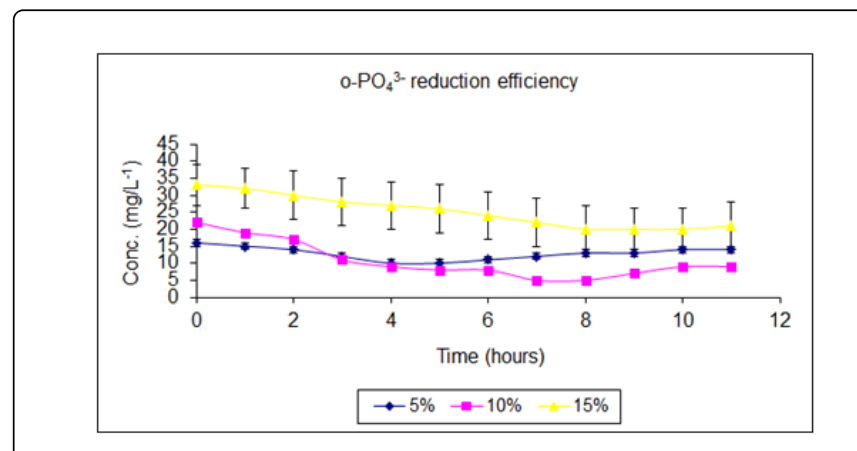

Figure 7: Comparison of $\mathrm{PO}_{4}{ }^{3-}$ removal efficiency in a denitrification step using 5,10 and $15 \%$ organic carbon dose in a lab-scale SBR treating wastewater, $(n=6)$.

\section{Conclusion}

Organic carbon in effluent from the anaerobic SBR can be used as a carbon source for anoxic denitrification and phosphorus removal. However, the denitrification rate is affected by the organic carbon load used. The best denitrification and phosphorus removal efficiencies are achieved with $10 \%$ (of the anoxic SBR operational volume) of the anaerobic effluent. Except $\mathrm{o}-\mathrm{PO}_{4}{ }^{3-}-\mathrm{P}(8 \pm 1 \mathrm{mg} / \mathrm{L})$ and TKN $(35 \pm 4$ $\mathrm{mg} / \mathrm{L}$ ) all other parameters (BOD, TCOD, SCOD, TP, TSS, $\mathrm{NH}_{4+}-\mathrm{N}$ and turbidity) in the denitrified effluent met permissible discharge standards when $10 \%$ (of anoxic bioreactor) organic load was used.

\section{Acknowledgements}

This study received financial support from the Swedish International Development Co-operation Agency (Sida)/Department of Research Co-operation (SAREC) under the East African Regional Programme and Research Network for Biotechnology Policy Development (BIO-EARN).

\section{References}

1. Darshini PP, Sharpudin J (2016) Bioremediation of industrial and municipal waste water using bacterial isolates international. Journal of Engineering Sciences \& Research Technology 5: 173-177.

2. Jahangir MMR, Richards KG, Healy MG, Gill L, Müller C, et al. (2016) Carbon and nitrogen dynamics and greenhouse gas emissions in constructed wetlands treating wastewater: A review. Hydrol Earth Syst Sci 20: 109-123.

3. Chang NB (2011) Making a progress to speed up the nitrification and denitrification processes in novel biosorption activated media: can archaea be in concert with anammox? J Bioprocess Biotechniq 1: 103e.

4. Le HT, Jantarat N, Khanitchaidecha W, Ratananikom K, Nakaruk A (2015) Development of sequencing batch reactor performance for nitrogen wastewater treatment. J Microb Biochem Technol 7: 363-366.

5. Naik SS, Setty YP (2011) Biological denitrification of wastewater in a fluidized bed bioreactor by immobilization of pseudomonas stutzeri using poly propylene granules. Int J Biotechnol Appl 3: 106-109.

6. Danial O, Salim MR, Salmiati (2016) Nutrient removal of grey water from wet market using sequencing batch reactor. Malaysian Journal of Analytical Sciences 20: 142-148. 
Citation: David NM, Eliud Nyaga MN, George O, Frank K, John O, et al. (2017) Evaluation of Organic Carbon from Anaerobic Sequencing Batch Reactor Effluent as a Carbon Source for Denitrification. J Bioengineer \& Biomedical Sci 7: 214. doi:10.4172/2155-9538.1000214

Page 6 of 6

7. Rossi F, Motta O, Matrella S, Proto A, Vigliotta G (2015) Nitrate removal from wastewater through biological denitrification with OGA 24 in a batch reactor. Water 7: 51-62.

8. Naili O, Benounis M, Darbouche A, Kheddouma A (2015) Biological denitrification using pure cultures isolated from wastewater treatment plant of khenchela (Eastern Algeria). J Biol Environ Sci 9: 33-39.

9. Marin JCA, Caravelli AH, Zaritzky NE (2016) Nitrification and aerobic denitrification in anoxic-aerobic sequencing batch reactor. Bioresource Technology 200: 380-387.

10. Qian J, Zhou J, Zhang Z, Liu R, Wang Q (2016) Biological nitrogen removal through nitritation coupled with thiosulfate-driven denitritation. Scientific Reports 6: 27502.

11. Azhdarpoor A, Mohammadi P, Dehghani M (2016) Simultaneous removal of nutrients in a novel anaerobic-anoxic/aerobic sequencing reactor: removal of nutrients in a novel reactor. International Journal of Environmental, Science and Technology 13: 543-550.

12. Khanitchaidecha W, Nakaruk A, Koshy P, Futaba K (2015) Comparison of simultaneous nitrification and denitrification for three different reactors. BioMed Research International.

13. Lochmatter S, Maillard J, Holliger C (2014) Nitrogen removal over nitrite by aeration control in aerobic granular sludge sequencing batch reactors. Int J Environ Res Public Health 11: 6955-6978.

14. Singhal N, Perez-Garcia O (2016) Degrading organic micropollutants: The next challenge in the evolution of biological wastewater treatment processes. Frontiers in Environmental Science 4: 1-5.

15. Fernandes H, Jungles MK, Hoffmann H, Antonio RV, Costa RHR (2013) Full-scale sequencing batch reactor (SBR) for domestic wastewater: Performance and diversity of microbial communities. Bioresource Technology 132: 262-268.

16. Abubakar S, Latiff AA, Lawal IM, Jagaba AH (2016) Aerobic treatment of kitchen wastewater using sequence batch reactor (SBR) and reuse for irrigation landscape purposes. American Journal of Engineering Research 5: 23-31.

17. Aponte-Morales VE, Tong S, Ergas SJ (2016) Nitrogen removal from anaerobically digested swine waste centrate using a laboratory-scale chabazite-sequencing batch reactor. Environmental Engineering Science 33: 324-332.

18. Kurniawan A, Kwon SY, Shin JH, Hur J, Cho J (2016) Acid fermentation process combined with post denitrification for the treatment of primary sludge and wastewater with high strength nitrate. Water 8: 117.
19. Mutua DN, Njagi ENM, Orinda G, Obondi G, Kansiime F, et al. (2016) Biological treatment of meat processing wastewater using lab-scale anaerobic- aerobic/anoxic sequencing batch reactors operated in series. J Bioremed Biodeg 7: 362.

20. Tang B, Wu G, Wang H, Guan Y (2016) Nitrous oxide emission depending on the type of electron acceptor by a denitrifying phosphorus removal sludge. Global NEST Journal 18: 251-258.

21. Zou S, Yao S, Ni J (2014) High-efficient nitrogen removal by coupling enriched autotrophic-nitrification and aerobic-denitrification consortiums at cold temperature. Bioresource Technology 161: 288-296.

22. Haiming Z, Xiwu L, Abualhail S, Jing S, Qian G (2014) Enrichment of $\mathrm{PAO}$ and dPAO responsible for phosphorus removal at low temperature. Environ Prot Eng 40: 67-80.

23. Cydzik-Kwiatkowska A, Rusanowska P, Głowacka K (2016) Operation mode and external carbon dose as determining factors in elemental composition and morphology of aerobic granules. Arch Environ Prot 42: 74-79.

24. Rahman A, Riffat R, Okogi S, Takacs L, Al-Omari A (2016) Evaluation of anoxic heterotrophic yield using multiple calculation methods. Int J Environ Res 10: 255-264.

25. Obaja D, Macé S, Mata-Alvarez J (2005) Biological nutrient removal by a sequencing batch reactor (SBR) using an internal organic carbon source in digested piggery wastewater. Bioresour Technol 96: 7-14.

26. Puig S, Corominas LI, Balaguer MD, Colprim J (2007) Biological nutrient removal by applying SBR technology in small wastewater treatment plants: Carbon source and $\mathrm{C} / \mathrm{N} / \mathrm{P}$ ratio effects. Water Sci Technol 55: 135-141.

27. Fabregas M (2004) SBR technology for wastewater treatment: Suitable operational conditions for nutrient removal. PhD thesis, University of Girona, Spain.

28. Xiao Y, Xiao Q, Xiang S (2014) Modeling of simultaneous partial nitrification, anammox and denitrification process in a single reactor. J Environ Anal Toxicol 4: 204

29. de S Moraes B, Orrú JGT, de Andrade CC, Fonseca DF, Foresti (2014) Shortcut nitrification-denitrification coupled with sulfide oxidation in a single reactor. J Microb Biochem Technol 6: 087-095. 